\title{
Agricultural Water Security: Research and Development Prescription for Improving Water Use Efficiency, Availability and Quality
}

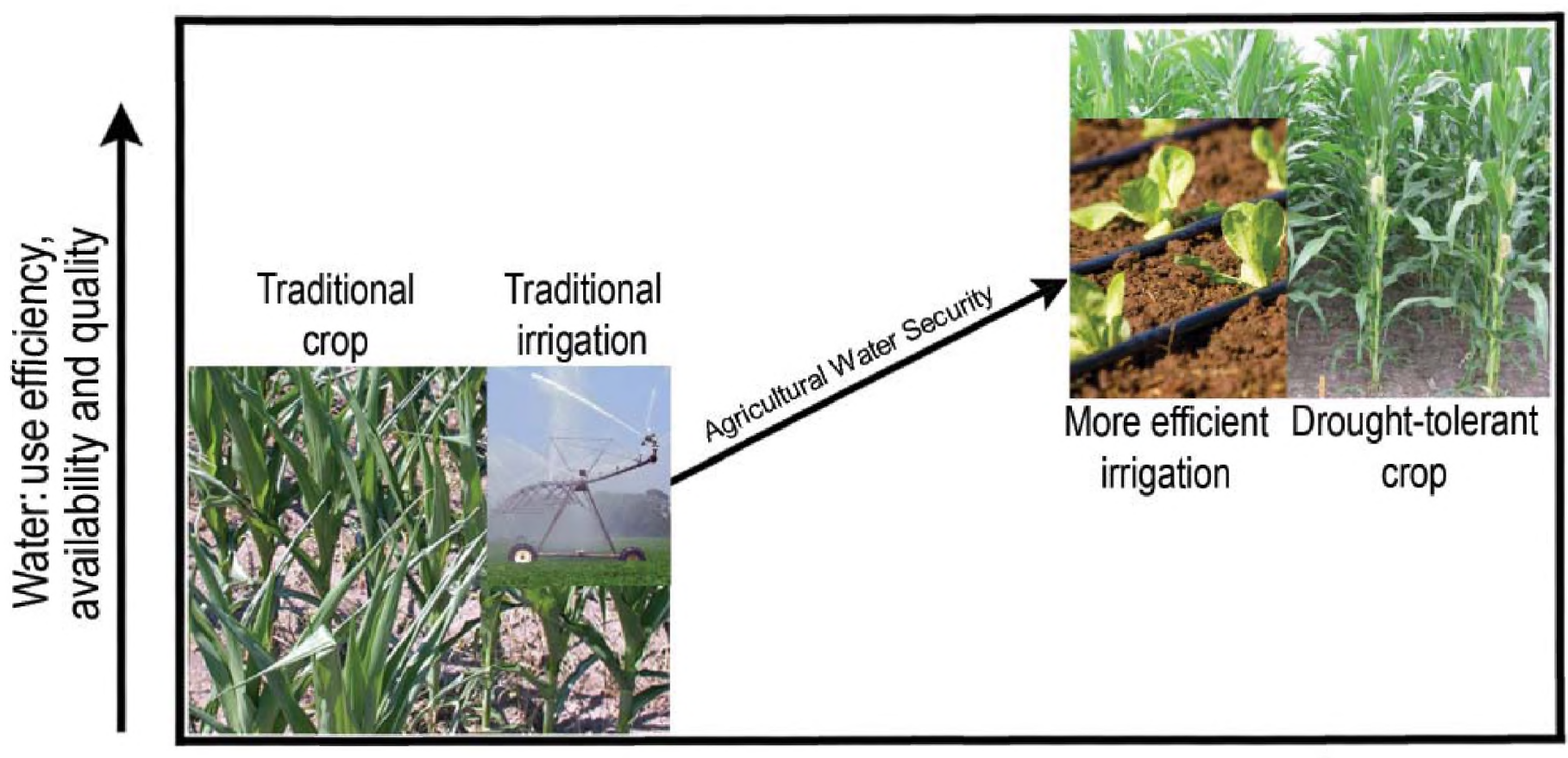

Improvements: agronomic, agroecological, engineering and genetic

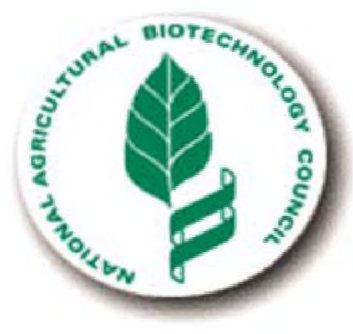

"Water is the staff of life."

-Traditional saying

"Our water crisis should occasion grave concern but not panic. We have solutions available: now we need a national commitment to pursue them."

-Robert Glennon (2009)2

\footnotetext{
${ }^{1}$ In Canada and the United States.

2 Glennon R (2009) Unquenchable: America's Water Crisis and What To Do About It. Washington, DC: Island Press. Photographs by permission of: (crops) Drs. Kevin Steffey and Michael Gray (University of Illinois at Urbana-Champaign and the University of Wisconsin-Madison); (irrigation systems) Dr. H. Perlman (US Geological Survey) and iStockphoto LP.
} 


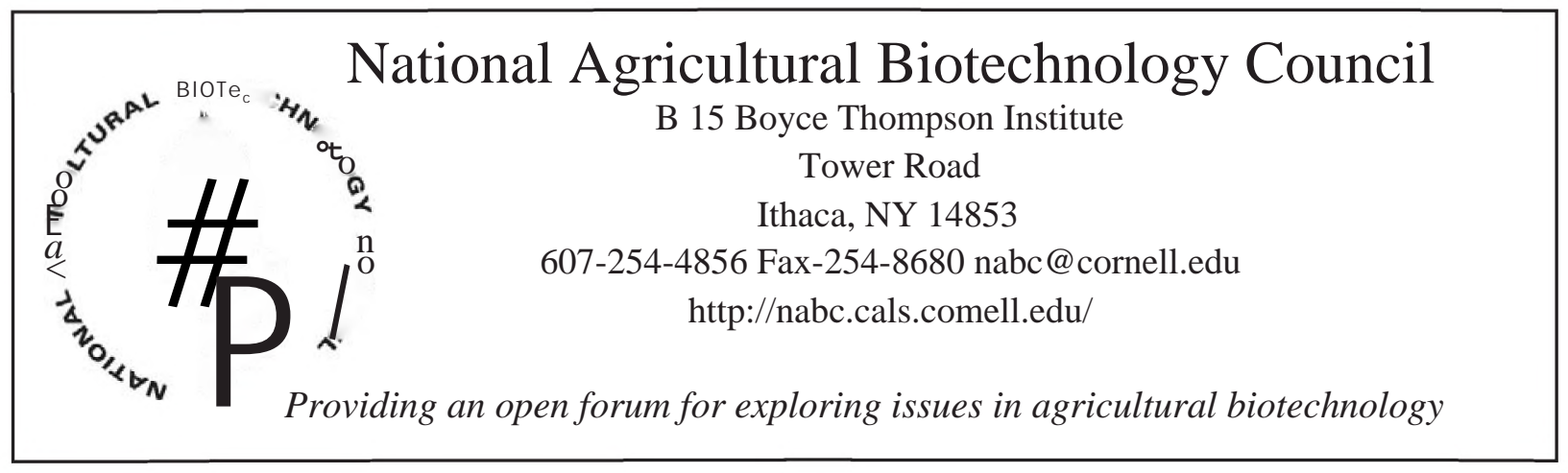

December 31, 2010

The National Agricultural Biotechnology Council (NABC), a consortium of over thirty major agricultural research and educational institutions in the United States and Canada, has developed Agricultural Water Security: Research and Develop ment Prescription for Improving Water Use Efficiency, Availability and Quality. This document outlines the challenges of agriculture's need for water (on average one liter of water for every Calorie of food consumed) and its impact on water quality. Research, development and implementation prescriptions are suggested for improv ing agriculture's eff ciency of use of water, expanding the supply of water for agri culture and reducing agriculture's impact on water quality.

NABC identif es water as a critical issue for agriculture. This document and NABC's annual conference in 2012 provide a summary and an open-forum report on needed action.

Bill F. McCutchen

Associate Director

Texas AgriLife Research

Texas A\&M University System

College Station, TX 77843
Ralph W.F. Hardy

President

NABC

Boyce Thompson Institute for Plant Research, Inc. Ithaca, NY 14853 


\section{Summary}

The major and growing challenge for society is water. Water is essential for agriculture. Agriculture uses $70-80 \%$ of withdrawn fresh water. The global need by 2050 for increased food/feed produc tion for 3.0 billion additional humans and for increased meat consumption in emerging economies coupled with the biobased industrial product opportuni ties will greatly expand agriculture' $s$ need for water. Climate change also will impact water and agriculture. The effects of crop and animal production on water quality — nutrient and pesticide contami nation and soil salinization-need to be reduced to meet increasingly stringent quality standards. Expanded, integrated, focused agronomic, agroecological, en gineering and genetic research, develop ment and implementation are essential to improve water -use eff ciency, avail ability and quality as prescribed here for agricultural water security and food se curity for Canada and the United States. 


\section{Introduction}

Water has always been an important issue for agriculture; it is now critically important. Improvements in water use and availability must be achieved to meet the food and feed needs of the projected 9.5 billion humans by 2050 and to provide biofeedstocks for the expanding biobased industrial products market. Shnultaneouslyagriculture's impact on water quality - via fertilizers, animal waste products, pesticides and salinity-must be reduced to meet the increasingly stringent water-quality standards. This paper outlines the water-related challenges faced by ag riculture and identif es research and development opportunities for improving quality and increasing ef $\mathrm{f}$ ciency of use and availability, focusing on the United States and Canada 1. Policy for water use (e.g. CAST 20 09²) and changes by society and industry outside of agriculture are not addressed.

\section{Challenges}

\section{Agriculture's Need for Water}

Agriculture's need for non-saline water is huge, criti cal, and growing, as documented by the following:

- $70 \%$ to $80 \%$ of withdrawn fresh water is used by agriculture, whereas $20 \%$ to $30 \%$ is used by indus- • try and directly by humans and municipalities.

- Yield of plant-based rain-fed agriculture is limited to a signi f cant extent by less-than-optimal avail ability of water during the growing season, from brief spells of moisture stress to periodic major droughts. Optimum yield is restricted by up to $50 \%$ or more by limitations in water and solar radiation.

- Most plant species are highly inef $f$ cient users of water. Major crops - wheat, soybean, etc. - tran spire through stomata over 150 molecules of water for each net molecule of $\mathrm{CO}$, captured by photo synthesis.

- Food production requires lar ge amounts of water . A rule of thumb is that 1-2 liters of water are used to produce one food calorie (Cal), i.e. about 5001,000 gallons of water every day for an average dai ly ration of 2,500 Cals. However, the range is large. • For example, production of $1 \mathrm{~kg}$ of wheat requires between 400-2,500 liters depending on variety, fer tilization, moisture stress and management. This range of values provides hope for improvement in eff ciency. Almost all of the water needed for meat and milk production is used to provide feed for live-

\footnotetext{
${ }^{1}$ Several NABC Reports contain presentations that address aspects of agriculture and water, e.g. 16.19. 20 and 21. The 2012 conference will focus on agriculture and water.

${ }^{2}$ Council for Agricultural Science and Technology (CAST) (2009) Water, People, and the Future: Water Availability for Agri culture and the United States. Issue Paper 44. Ames, IA: CAST.
}

stock and is not directly consumed by the animals.

- Projected world population growth to 9.5 billion by 2050 , coupled with increased meat consumption by people in emer ging economies such as China, will greatly increase the need for water for food and feed production by agriculture; alternatively, di etary choices will be restricted by water limitations. Different agricultural production systems-e.g. large-scale traditional, genetically engineered crops, organic and locally produced - may require dif ferent prescriptions for improving water-use eff ciency and reducing their environmental footprints, al though the major water requirement for each will be for primary plant production and, therefore, similar.

- The United States and Canada - as exporters of com, soybean, wheat, canola, etc.- - are, effectively, major providers, not only of food and feed but also indirectly of water, to other parts of the world.

- Major new industrial product opportunities for agriculture, in the biobased or green economy , will require water to grow dedicated biomass crops - switchgrass, miscanthus, sorghum, algae, etc. - as well as for processing to fuels, chemicals and materials.

Irrigation for agricultural crop production is essen tial in low-rainfall regions of the world, e.g. South Asia, the Middle East and North Africa. Although irrigation is used on less than $20 \%$ of agricultural land in the United States and even less in Canada, in some areas it is critical, e.g. the Central Valley of California, Arizona and the High Plains states. Half of the fruits and vegetables consumed in the Unit ed States come from irrigated $\mathrm{f}$ elds in California. Years of increasing irrigation and urbanization are challenging water security in these areas. Groundwater aquifers are being depleted in the High Plains. Surface water sources are being fully used in Cali- 
fomia and Arizona, such that agriculture is in grow ing competition with industrial, environmental and ecological, recreational and expanding urban users.

- Desertif cation is increasing globally, but almost ex clusively outside of Canada and the United States.

- Global climate change is projected to have negative and positive effects on agriculture, depending chief ly on geographical location. Weather extremes will increase in intensity and frequency, including tem perature and rainfall; some areas will become wet ter, some drier. It is projected that southern latitudes will be less favorable for crop production whereas northern latitudes, e.g. the Canadian prairies, may be more favorable ${ }^{12}$."

\section{Agriculture's Impact on Water Quality}

Agriculture, both intensive grain and animal production, has negative impacts on water quality as do industrial and municipal uses. Contamination of water-ground, rivers, lakes - with fertilizer, nutrients and other com ponents of animal waste, and pesticides, is a problem. Salination is a byproduct of irrigation and fertilization.

- Fertilization is essential for high-yield grain pro duction, e.g. corn and wheat. Up to $40 \%$ of fertil izer $\mathrm{N}$ (and other applied nutrients) are not taken up and eventually some enters rivers, lakes, groundwater and coastal waters, producing algal blooms and depleting oxygen levels. These hypoxic or dead zones are signif cant; in 2009, the hypoxic zone in the Gulf of Mexico was estimated at 3,000 square miles. The EPA has identif ed over 6,000 bodies of water in the United States, of which the quality is impaired by excessive nutrient content.

- Concentrated animal production-feedlots, lar ge dairy facilities, poultry houses and swine farmsrequire management of waste nutrients and reduc tion of contamination of water.

- Pesticide, including herbicide, use — regulated by EPA in the United States and Health Canada's Pest Management Regulatory Agency in Canada-is standard practice for most plant agriculture. Weed control with herbicides eliminates the water lost to

\footnotetext{
${ }^{1}$ Eaglesham A et al. (Eds.) (2009) NABC Report 21: Adapting Agriculture to Climate Change. Ithaca, NY: National Agricultural Biotechnology Council.

2 Bates BC et al. (Eds.) (2008) Climate Change and Water. Technical Paper VI of the Intergovernmental Panel on Climate Change. Geneva: IPCC Secretariat.
}

weed growth, and, similarly, pest control improves the eff ciency of water use in food and feed produc tion. Some of the early pesticides, e.g. the herbicide atrazine, were degraded only slowly and reached groundwater. Pesticide-detection systems have be come highly sensitive and the signi f cance of lowlevel, but now detectable, pesticide residues in wa ter has become a controversial issue.

- Intensive irrigation and fertilization can increase the salinity of soil (and of groundwater), negatively affecting crop production.

- Erosion after conventional tillage leads to loss of topsoil to rivers causing contamination, not only with particulates, but also with agricultural chemi cals carried by the soil.

- Water f ows, necessary for ecological and ecosys tem functions, directly compete with agriculture.

- Numeric nutrient water-quality standards for lakes, rivers and reservoirs are being developed and will increasingly impact agricultural production sys tems.

Although impacts by agriculture on water quality prob ably will never be completely eliminated, signi f cant progress is being made, and this ef fort must continue.

The above challenges dictate expanded research and development ef forts in Canada and the United States to increase water availability and use ef $f$ ciency in agriculture and decrease adverse impacts on water quality.

\section{Research and Development Prescriptions \\ Improving Agriculture's Water Use}

The opportunities for improving the ef f ciency of wa ter use by agriculture are genetic, agronomic includ ing agroecology, engineering, and possibly chemical. Genetic approaches have signi f cant potential with traditional plant breeding being supplemented with molecular genetic approaches. The f rst commercial product-drought-tolerant com-is scheduled for farmers' felds in 2011. Agronomic and agroecological approaches are well established, e.g. conservation tillage and improved methods of delivering/managing irrigation water, but there is great potential for water savings through improved irrigation, management and other technologies. Chemical applications may mini- 
mize negative responses of crops to brief periods of water shortage.

\section{Genetic, Agronomic, Agroecological, Engineering and Chemical Approaches}

Research on the effects of abiotic stresses on plants, in cluding drought, is increasing. For example, the HAR $D Y$ gene, when expressed in rice, improves water -use eff ciency by increasing photosynthetic assimilation while reducing transpiration; the $\operatorname{csp} B$ gene is an exam ple from corn. Several plant-breeding companies have disclosed plans to market com with increased drought resistance and improved yield stability. Industry will probably extend this initial breakthrough in improved water-use eff ciency and drought tolerance to other ma jor-acreage crops-soybean, wheat, cotton-whereas lower-acreage crops-barley, oats, horticultural prod ucts-will probably require public-sector R\&D. In ad dition, public-sector research probably will be a major identif er of relevant genes to enable improved drought tolerance and increased water-use eff ciency. Irrigation of perennial vine and tree crops will, in the near future, benef $\mathrm{t}$ more from appropriate timing of water applica tions than from genetics.

The above genetic examples of improved drought tolerance employed traditional breeding and selection of genes found in model plants or bacteria. Another ge netic approach is to study species that are inherently more drought tolerant, such as sor ghum. The genetic basis for sorghum's relative tolerance of moisture def ciency is being elucidated by comparison of its genom ic sequence with those of more drought-sensitive plant species. A longer-term, more-high-risk possibility is to increase water-use eff ciency by conversion of crops with $\mathrm{C}_{3}$ photosynthesis - wheat, soybean, rice, etc.- - to become $\mathrm{C}_{4}$ photosynthesizers like corn and sor ghum, although over thirty years of genetic and chemical at tempts in this endeavor have been unsuccessful. How ever, the exploding, massive database and availability of new tools with more interdisciplinary approaches are reigniting this approach with the possible produc tion of intermediate $\mathrm{C}_{3} / \mathrm{C}_{4}$ crops. A related approach is the study of the genetic and biochemical pathways of CAM species, e.g. the common ice plant ( Mesembrycmthemum crystallinum) and pineapple that have wateruse eff ciencies of up to ten times those of major crop plants. These plants absorb and store CO., during dark ness and release it slowly during the day, thus reducing transpiration so that they thrive in hot, dry conditions.
Also possible is the development of crops that are grown at times when evapotranspiration demands are low. For example, rapidly maturing annual crops that are planted earlier or later would avoid maximum sum mer water loss.

Application of specif c chemicals may mitigate the effects of drought. An example of a possible product is an ethylene inhibitor that protects plants from the ef fects of moderate moisture dtf ciency. Another example is stimulating production of the plant hormone abscisic acid to decrease stomatal opening, thereby reducing transpiration. A benef cial byproduct of future elevat ed atmospheric $\mathrm{CO}_{2}$ levels will be increased stomatal closure, thereby reducing transpiration and increasing water-use eff ciency.

Signif cant genetic variation in crop plants has been identif ed to reduce transpiration, such as waxy covering on leaf surfaces and more-ef $f$ cient stomatal responses to water stress, and longer, more-branched roots and more-dense and longer root hairs for more eff cient uptake of water and nutrients.

An advantage of abiotic-stress resistance versus biotic-stress resistance is that genetic and chemical so lutions to abiotic stress should be long-lived, whereas resistance almost always develops to biotic stress prod ucts, both genetic and chemical.

The benef ts from agronomic, agroecological and engineering-improved water use are well established and there is major opportunity for more in the future. Substantial contributions to date include:

- tillage modif cations - from deep plowing to mini mum till to vertical till or no till to improve soil structure,

- expanded use of cover crops,

- improvement in irrigation-water delivery and use from ineff cient $\mathrm{f}$ ood and furrow to precision irri gation, lined irrigation ditches, drip irrigation and micro-sprinklers,

- hydroponics for intensive vegetable production.

Potential future benef ts include:

- $\quad$ soil-moisture sensing (in situ and remote) to guide management practices,

- mathematical modeling of crop-water requirements,

- precision agriculture,

- integrated cropping systems,

- management of complex soil water properties to enhance crop productivity, 
- salt-water management in the root zone,

- irrigation technology including water-system auto mation to achieve water savings,

- $\quad$ irrigation water capture and reuse from develop ment of new technologies and control systems,

- soil amendments for improved water-use eff ciency, e.g. incorporation of long-lived biochar,

- drainage and water-quality management to improve water quality,

- integrated climate and land-use hydrologic-agroecological modeling systems for optimal location of agricultural lands in watersheds to maximize yield and natural assimilation capacity to minimize excess nutrients from agricultural production.

Some of the above will benef $t$ both water-use eff cien cy and water quality.

\section{Availability - Salt Tolerance and Reuse to Expand the Supply of Water for Agriculture}

Fresh water constitutes $2 \%$ of the global supply, whereas $98 \%$ is saline. Development of crops toler ant of saline water is the major opportunity (for sa linity); economically feasible desalination of wa ter would hugely expand the supply of water for humans, but may still be too expensive for agriculture.

Land plants evolved from halophytes, but, in the process, lost their tolerance of salinity However, there is signif cant variability in salinity tolerance of some crop plants, e.g. rice. Genetic approaches have increased sa linity tolerance in tomato. Improving salinity tolerance of crops by $20 \%$ to $30 \%$ through traditional and mo lecular genetic breeding would have global impact, as productive acreage could be expanded and low-quality water employed for food production, allowing fresh wa ter to be used to meet human and environmental needs.

Use of low-quality watei; e.g. brackish or reclaimed water, for irrigation of feed crops and industrial uses represents an opportunity to expand the water supply for food production. Supplementing tree crops with low-quality water at certain times of the year is another possibility. However, water used to grow food crops, e.g. fruits and vegetables, must be safe at certain peri ods so as not to contaminate the harvested entity.

Research is needed to develop cost-efective wastewater and reuse options for suburban landscapes and agriculture. Sustainable water-management strategies will increasingly require more immediate reuse for all purposes.

\section{Reducing Agriculture's Impact on Water Quality Nutrient Contamination}

Unused and waste nutrients from crop and animal ag riculture can lead to contamination of rivers, lakes and groundwater. Nutrient management in crops is improv ing, e.g. com used to require about $1.2 \mathrm{lb} \mathrm{N}$ fertilizer per bushel, whereas the current tar get is $0.75 \mathrm{lb}$. Fer tilizer nitrogen delivery is being micro-managed to maximize crop recovery, driven in part by the need to minimize input costs. Geneticists are developing crops with increased nitrogen-use ef f ciency. In the long term, a high-reward/high-challenge research op portunity is self-nitrogen-fertilizing non-legume crops, thereby eliminating unused nitrogen and most of the nitrogen contamination problem in water from crop production. One revolutionary futuristic approach, potentially achievable with today's molecular tools is to induce crop plants to form ste $n i$ modules contain ing rhizobia with photosynthetic capability (similar to those that nodulate the stems of Aeschynomene speciev), thereby eliminating the large energy draw from the plant to support biological nitrogen $\mathrm{f}$ xation in root nodules of today's legume and tomorrow's non legume crops. In addition to the huge bene $\mathrm{ft}$ to water quality, these would bring a major reduction in agri cultural use of energy to synthesize fertilizer nitrogen.

Waste nutrients from animal agriculture are be ing recycled to soils under protocols that limit water contamination. Low-phytate plants, animals produc ing phytase — e.g. the Enviropig ${ }^{\mathrm{TM}}$ — and phytase-supplemented feeds are being commercialized to reduce phosphate content in animal waste and minimize con tamination of rivers and lakes.

\section{Pesticide Contamination}

Herbicide- and pest-resistant crops have less environ mental impact on water, as well as direct reduction in water contamination by reduction in herbicide and in secticide sprays or use of compounds with faster deg radation, e.g. glyphosate versus atrazine. A recent NRC report suggests that the major benef $t$ from commercial transgenic crops is environmental ${ }^{3}$, but the increase in gyphosate-resistant weeds is a concern.

\footnotetext{
3 National Research Council (2010) The Impact of Genetically Engineered Crops on Farm Sustainability in the United States. Washington, DC: The National Academies Press.
} 


\section{Conclusion}

There are multiple agricultural research and development opportunities to improve water availability, eff ciency of use, and quality-genetic, agronomic, agroecological, engineering and chemical. Immediate, expanded, integrated and focused R\&D investment by the public and private sectors-in genetics, chemistry, agronomy, agroecology and engineering-is our recommended prescription for agricultural water security and food secu rity in the United States and Canada. 
Boyce Thompson Inst it ute David Stern

President

Cornell University

Margaret E. Smith

Associate Director,

Cornell University Agricultural Experiment Station

Michigan State Univer sit y

Steven G. Pueppke

Director, Michigan Agricultural Experiment Station and

Associate Vice-President for Research and Graduate Studies

NORTH DAKOTA STATE UNIVERSTTY

Ken Grafton

Dean, College of Agriculture, Food Systems, and Natural Resources and Director, North Dakota

Agricultural Experiment Station

Or egon St ate Univer sity

Lawrence R. Curtis

Associate Dean,

College of Agricultural Sciences

Pur due Univer sity

Marshall Martin

Senior Associate Director Agricultural Programs

and Assistant Dean of Agriculture

The Pennsyl vania St at e Univer sity

Bruce A. McPheron

Dean, College of Agricultural Sciences

Univer sity of al ber ta

John J. Kennelly

Dean, Faculty of Agricultural, Life

and Environmental Sciences
Clemson Univer sity

Susan F. Barefoot

Chief Operating Officer,

Clemson University Experiment Station and

Associate Dean, Food Safety and Nutrition

Mc Gill Univer sity - Mc Donald Campus

Chandra A. Madramootoo

James McGill Professor and Dean,

Faculty of Agricultural and

Environmental Sciences for Research and

Technology Transfer

Nor th Car ol ina St at e Univer sity

Kenneth R. Swartzel

Coordinator,

Bioprocessing Programs, College of Agriculture and Life Sciences

Ohio State Univer sity

Steven A. Slack

Associate Vice President for Agricultural Administration

and Director, Ohio Agricultural Research and Development

Center

Okl ahoma St ate Univer sity

Clarence $\mathrm{E}$. Watson

Associate Director,

Agricultural Experiment Station

South Dakota St at e Univer sity

Thomas Cheesbrough

Interim Director, Agricultural Experiment Station

Texas A\&M Univer sit y

Bill F. McCutchen

Associate Director,

Texas Agrilife Research

Univer sity of Ar izona

Eugene Sander

Vice Provost and Dean, College of Agriculture

and Life Sciences 
Univer sity Of Ar kansas

Mark J. Cochran

Associate Vice President for Agriculture-

Research and Director, Arkansas Agricultural

Experiment Station, Division of Agriculture

Univer sity of $C_{a l}$ if or nia-Davis

Neal Van Alfen

Dean, College of Agricultural and

Environmental Sciences

Univer sity of Geor gia

Robert N. Shulstad

Associate Dean for Research,

College of Agricultural and Environmental Sciences

Univer sity of Kent ucky

Nancy M. Cox

Associate Dean for Research

and Director, Agricultural Experiment Station

Univer sity of Manit oba

Michael Trevan

Dean, Faculty of Agricultural and

Food'Sciences

Univer sity of Missour i at Col umbia

Marc J. Linit

Associate Dean for Research and Extension,

College of Agriculture, Food and Natural Resources

Univer sit y of Saskat chewan

Graham J. Scoles

Associate Dean for Research,

College of Agriculture and Bioresources
Univer sity of Connecticut

Gregory Weideman

Dean and Director,

College of Agriculture and Natural Resources

Univer sity of Flor ida

Mark R. McLellan

Dean for Research and Director

Florida Agricultural Experiment Station

Univer sit y of Guelph

Robert Gordon

Dean,

Ontario Agricultural College

Univer sity of Il inois at Ur bana-Champaign

Jozef L. Kokini

Associate Dean of Research and

Director, Illinois Agricultural Experiment Station

Univer sity of Minnesota

F. Abel Ponce de Leon

Senior Associate Dean for Research and Graduate Programs, College of Food, Agricultural and Natural Resource Sciences and Associate Director, MAES

Univer sit y of Nebr aska-Lincoln

David Jackson

Associate Dean,

Agricultural Research Division

Univer sit y of Wisconsin

Molly Jahn

Dean,

College of Agriculture and Life Science

Washington State University

Ralph P. Cavalieri

Associate Dean, College of Agricultural, Human, and Natural

Resource Sciences and Director, Agricultural Research Center

This document was not signed by the NABC member from the USDA. 


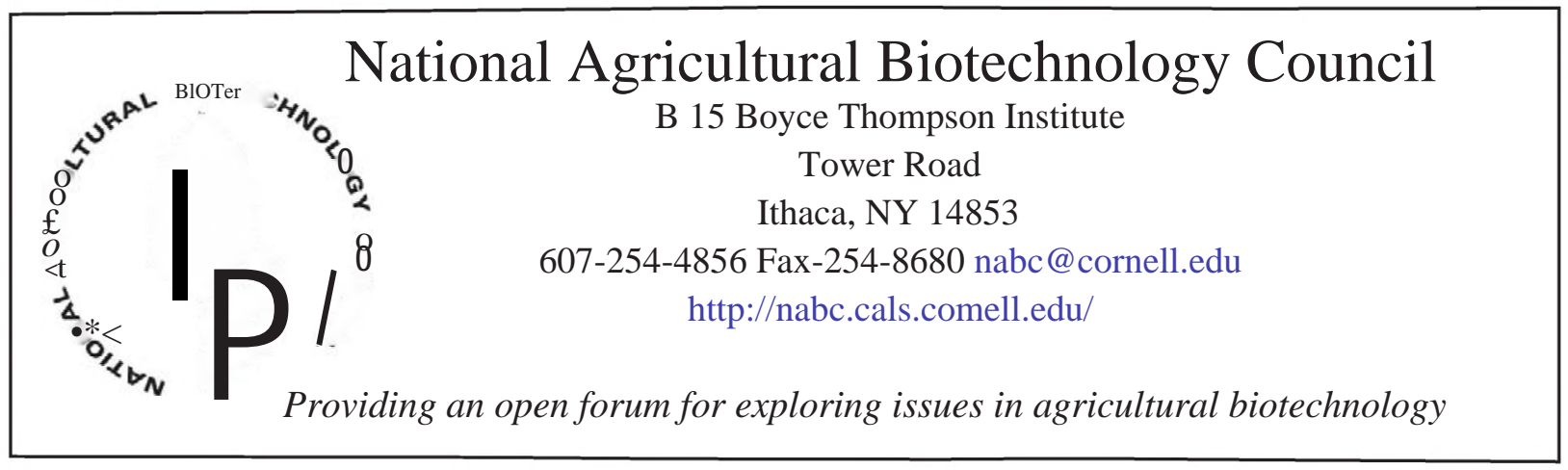

